UNITED STATES

DEPARTMENT OF THE INTERIOR

GEOLOGICAL SURVEY

PROGRESS REPORT ON STUDY OF

MAGNITUDE AND FREQUENCY OF FLOODS

ON SMALL DRAINAGE AREAS IN FLORIDA

By W. C. Bridges

U.S. GEOLOGICAL SURVEY

Open-File Report 77-478

Prepared in cooperation with

FLORIDA DEPARTMENT OF TRANSPORTATION 


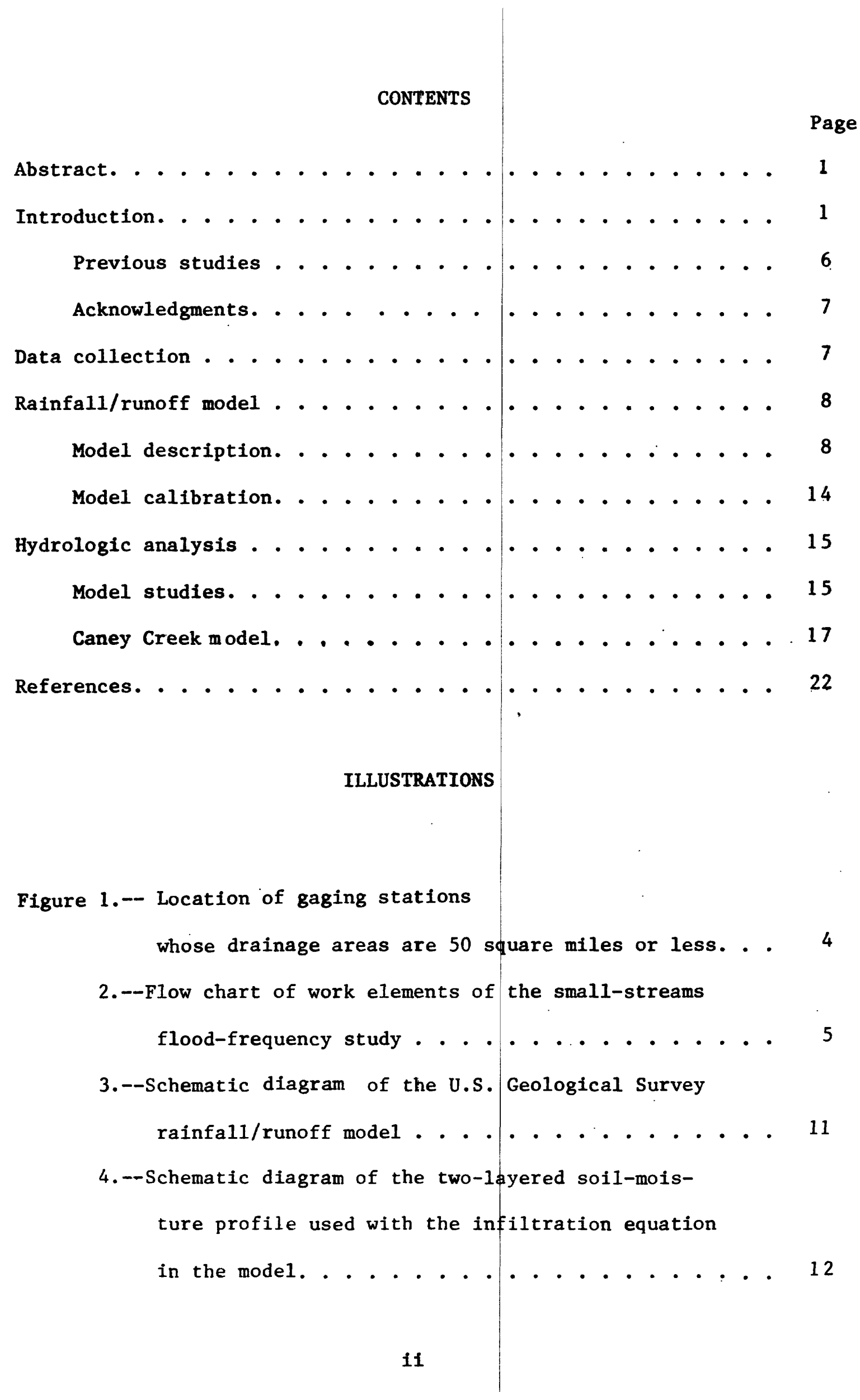




\section{ILLUSTRATIONS (Continued)}

Page

Figure 5.--Graph of observed flood peak versus simulated flood peak.................. 19

6.--Graph of flood frequency curve for Caney Creek using simulated flood peaks for 1902-68........ 21

\section{TABLES}

Tables 1.m-Identification and definition of the ten input parameters used in the rainfall/runoff model. . . 10 2.--Summary of model parameter values . . . . . . 16 3.--Calibration results listing the ten model parameters, observed runoff and peak discharge, and simulated runoff and peak discharge for 23 storms for Caney Creek . . . . . . . . . . 18 


\title{
PROGRESS REPORT ON STUDY OF MAGNITUDE AND FREQUENCY OF FLOODS ON SMALL DRAINAGE AREAS IN FLORIDA
}

By

W. C. Bridges

\begin{abstract}
Long-term flood records for small basins, especially those basins of less than 10 square miles, are almost nonexistent in Florida. In July 1967 a program was begun to develop a data base to extend short-term floodpeak records for small basins by use of the U.S. Geological Survey rainfall/runoff model. Concurrent rainfall and runoff data, for a 5- to 7year period, were used to calibrate a model for eight rainfall/runoff gaging stations. The standard error of estimate ranged from 25 to 50 percent. Twenty other rainfall/runoff stations are ready for calibration.

The Caney Creek station was calibrated, and the annual peaks simulated for 1902-68 were used as input to develop a flood-frequency curve using a log-Pearson Type III distribution.
\end{abstract}

\section{INTRODUCTION}

Because of the increase in the number of highways being constructed in recent years, more knowledge of the flood-frequency characteristics of small watersheds is needed for the design of safe and economical highway drainage structures. In the hydraulic design of such structures, one of the first considerations is the magnitude and frequency of the design flood or the maximum peak flow that can safely pass through 
the structure. The most desirable basis for a selection of the design discharge is a flood-frequency analysis of a long-term record of floods that have occurred at or near the site. With more than 50 percent of the Florida Highway bridge construction funds being spent to build bridges and culverts on small basins, there exists a great need for reliable flood-frequency information for small basins.

In 1958 the Florida Department of Transportation and the Geological Survey began a cooperative program to install crest-stage gages to obtain data on the annual maximum stage and discharge at selected sites in florida. The purpose of this program was to provide a data base of annual peaks to be used in a statewide flood-frequency report.

A crest-stage gage consists of a length of 2-in (inch) pipe set in a vertical position in the stream channel and records the peak stage of the stream. There are 41 crest-stage stations, 25 stations are on streams whose drainage areas are $50 \mathrm{mi}^{2}$ or less. Only four of the crest-stage stations are on streams whose drainage areas are less than $10 \mathrm{mi}^{2}$. Drainage areas range from 2.95 to $1,720 \mathrm{mi}^{2}$.

In Florida, as in most states, the emphasis had been on data collection for basins larger than $50 \mathrm{mi}^{2}$. Very little data are available for smaller basins, expecially those of less than $10 \mathrm{mi}^{2}$, for which records of more than 10 years in length are almost nonexistent. Records of less than 10 years now available are insufficient to develop frequency curves for an individual site or on a regional basis.

To meet this need for flood=frequency data on small basins the Geological Survey and the Florida Department of Transportation expanded the cooperative program in July 1967 to develop a data base and to extend short-term flood peak records on small basins using the U.S. Geological Survey Rainfall/Runoff Model (Dawdy, Lichty, and Bergman, 1972). 
Five rainfall/runoff gaging stations were established in December 1968. By July 1969 a total of 20 rainfa1l/runoff gaging stations were in the network. During July and September 1970 the rainfal1/runoff gagir $\mathrm{r}_{\text {, }}$ station network was expanded to 27 stations. At the request of the cooperator six urban rainfall/runoff gaging stations were added to the network in July 1971 which made a total of 33 rainfall/runoff gaging stations. Because of variable backwater problems three of the stations were discontinued, leaving a network of 30 rainfal1/runoff stations.

Drainage areas for the rainfall/runoff gaging stations vary froni 0.06 to $19.9 \mathrm{mi}^{2}$, and their distribution is as follows:

Drainage area

$\frac{\left(\mathrm{mi}^{2}\right)}{(\mathrm{mmber} o f}$ $0-0.5 \quad 0.5-1$ $1-2$ $2-5 \quad 5-10$ $10-20$ stations

13

$5 \quad 8$

9
4

Drainage areas for the crest-stage and regular gaging stations (on streams whose drainage areas are less than $50 \mathrm{mi}^{2}$ ) range from 2.95 to $49.1 \mathrm{mi}^{2}$, and their distribution is as follows:

\begin{tabular}{cccccccc}
$\begin{array}{c}\text { Drainage area } \\
\left(\mathrm{mi}^{2}\right)\end{array}$ & $1-2$ & $2-5$ & $5-10$ & $10-20$ & $20-30$ & $30-40$ & $40-50$ \\
\hline $\begin{array}{c}\text { Number of } \\
\text { stations }\end{array}$ & 0 & 1 & 5 & 11 & 20 & 13 & 8
\end{tabular}

Figure 1 is a map showing the location of the rainfa11/runoff gaging stations and crest-stage or regular gaging stations on streams whose drainage areas are $50 \mathrm{mi}^{2}$ or less. Of these, 36 percent are on streams whose drainage areas are $10 \mathrm{mi}^{2}$ or 1 ess.

The purpose of this report is to describe the general characteristics of the rainfall/runoff model and to summarize the modeling results using one example. A flow chart of the work elements of the project is shown in figure 2 . 


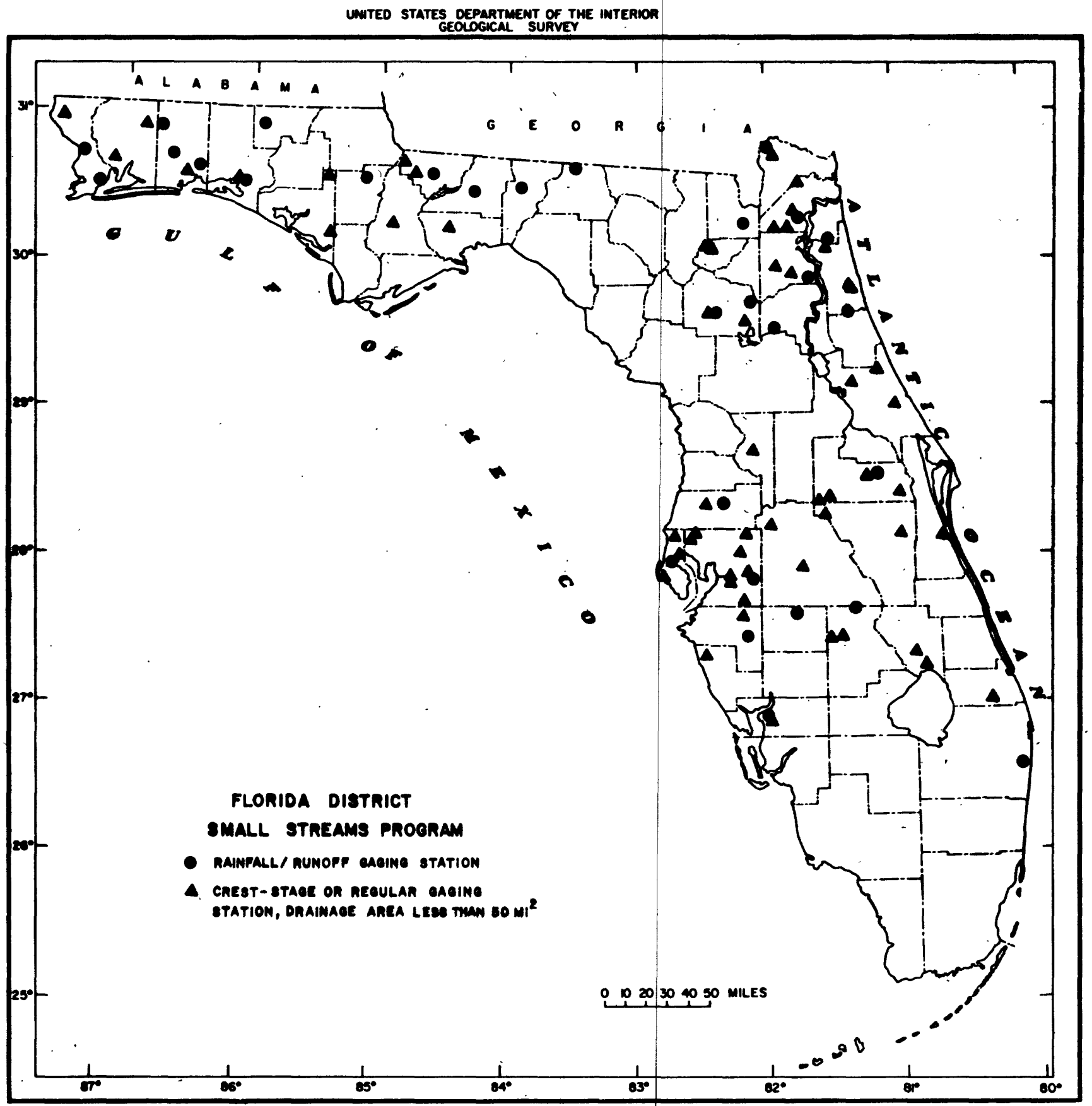

Figure 1. Location of gaging stafions whose drainage areas are 50 square miles or less. 


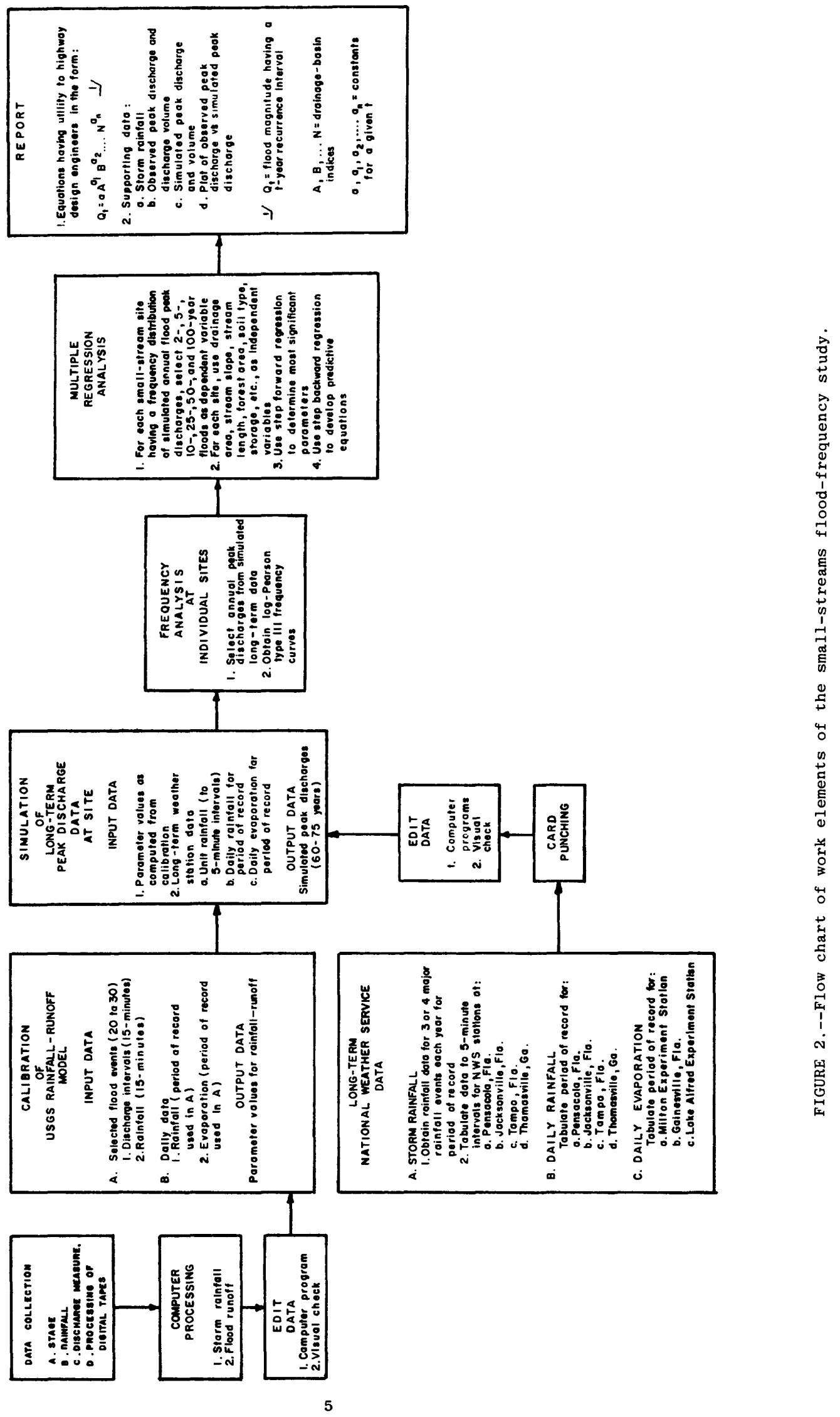


After model calibrations and peak simulations are completed (fig. 2), the next phase of the project will be to use the annual peaks from the crest-stage and regular gaging stations (with 10 or more years of record) and annual peaks from the rainfall/runoff gaging stations to develop statewide regional flood-frequencies. Individual frequency curves will be defined by mathematically fitting a log Pearson Type III distribution to the logarithms of the annual peaks using techniques recommended by the U.S. Water Resources Council (1976).

A technique using multiple regression analysis, described by Benson (1962; 1964), will be used to define regional relations between streamflow characteristics (dependent variable) and drainage-basin characteristics (independent variable). Flood estimating equations will be developed to determine the 2-,5-, 10-, 25-, 50-, and 100-year frequency floods for ungaged sites.

\section{Previous Studies}

Flood studies by Pride (1958) and Barnes and Golden (1966) proposed flood estimating techniques which were applicable to streams having drainage areas larger than $10 \mathrm{mi}^{2}$. In these studies two regional curves were developed using the individual station data with the index flood method. The first curve showed the variation of peak discharge as a dimensionless ratio the mean annual flood, for a given recurrence interval. The second related the mean annual flood to the size drainage area alone, or to the size area and percentage of area in storage in lakes and swamps. 


\section{Acknowledgments}

This study was conducted as part of a cooperative program with the Department of Transportation, State of Florida. Particular acknowledgment is given to William J. Rutledge, Jr., former Engineer of Drainage, for his interest in and support of this study.

For use of those readers who may perfer to use metric units rather than English units, the conversion factors for the terms used in this report are listed below:

\begin{tabular}{lll} 
Multiply English unit & \multicolumn{1}{c}{ By } & To obtain metric unit \\
inches (in) & 25.4 & millimeters (m) \\
feet (ft) & 0.3048 & meters $(\mathrm{m})$ \\
miles (mi) & 1.609 & kilometers $(\mathrm{km})$ \\
square miles $\left(\mathrm{mi}^{2}\right)$ & 2.590 & square kilometers $\left(\mathrm{km}^{2}\right)$ \\
cubic feet per second ( $\left.\mathrm{ft}^{3} / \mathrm{s}\right)$ & 0.02832 & cubic meters per second $\left(\mathrm{m}^{3} / \mathrm{s}\right)$
\end{tabular}

DATA COLLECTION

Concurrent rainfall and discharge data are collected at 30 rainfall/ runoff gaging stations. Each station is equipped with two digital recorders which simultansously record rainfall and stage. Of the 30 stations, 27 are equipped with 15-minute interval timers and 3 are equipped with 5-minute interval timers. The rainfall and stage parameters are digitally recorded on 16-channel paper tape for computer processing at a later date. Each rainfall/runoff gaging station is visited at 6- to 8-week intervals to 
service the instruments, remove the punched paper tapes, and measure streamflow. Routine measurements of flow are made to define and check for changes in the stage-discharge relation. In addition, speacial visits are made as required to measure flood flows and to make surveys for indirect measurement of extreme peak flows.

The punched-paper tapes of rainfall and stage are translated onto magnetic tape and stored in the U.S. Geological Survey computer file. These data are then edited and prepared for use in the rainfall runoff model. Data collection will continue until at least 25 significant floods have occurred.

The annual maximum peak discharge for each crest-stage and regular gaging station is entered into the peak-data computer file for later use in developing flood-frequency curves.

\section{RAINFALL/RUNOFF MODEL}

\section{Model Description}

A rainfall/runoff simulation model has been developed by the U. S. Geological Survey (Dawdy, Lichty, and Bergmann, 1972). This parametric rainfall/runoff simulation model uses rainfall data and daily potential evaporation data to predict flood volume and peak rates of runoff for small drainage areas. The rainfall/runoff model simulates the flood hydrograph at the basin outlet, based on the basin's antecedent moisture conditions and response to a specific rainfall. Three submodels of the hydrologic cycle are linked to form the model: antecedent moisture, infiltration, and surface runoff. 
The antecedent moisture component continually assesses the changes in soil moisture as a basis for determining the part of subsequent rainfall that becomes surface runoff. Assessment of moisture storage is made on a daily basis and on anit-time basis during storm periods. The infiltration component determines the part of the rainfall that becomes rainfall excess or surface runoff. The surface-routing component distributes the rainfall excess to form the outflow hydrograph.

Each of the components is represented by equations describing the physical actions taking place in the basin. Embedded in these equations are 10 parameters, or mathematical constants, which define the interrelations among the variables in the equations. The 10 parameters utilized in the model are listed in table 1 along with descriptions of the parameters. The flow diagram in figure 3 demonstrates the relation between the components, parameters, and variables used by the model.

The antecedent moisture accounting component controls the gross movement of moisture within the soil. It includes four parameters as listed in table 1. Figure 4 is a schematic diagram of the soil moisture accounting procedure. The total moisture in storage in the soil column is divided into two parts. The first part is the unpatterned area which contains the BMS (base moisture storage) at a soil moisture varying from field capacity to wilting-point conditions. The second part is SMS (surface moisture storage) near saturation and is represented by the hachured area. It is assumed that the total infiltrated soil column is near saturation. 


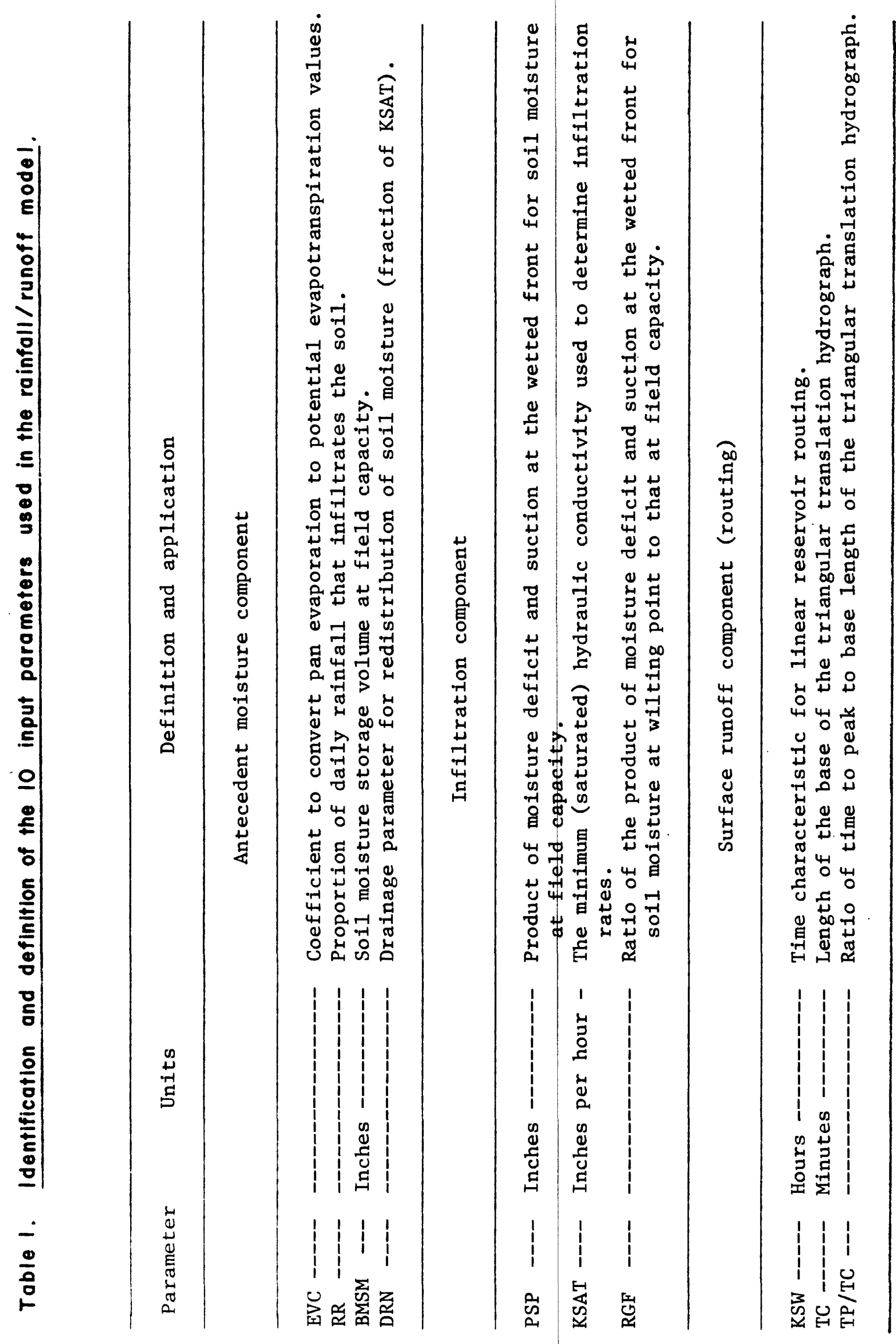




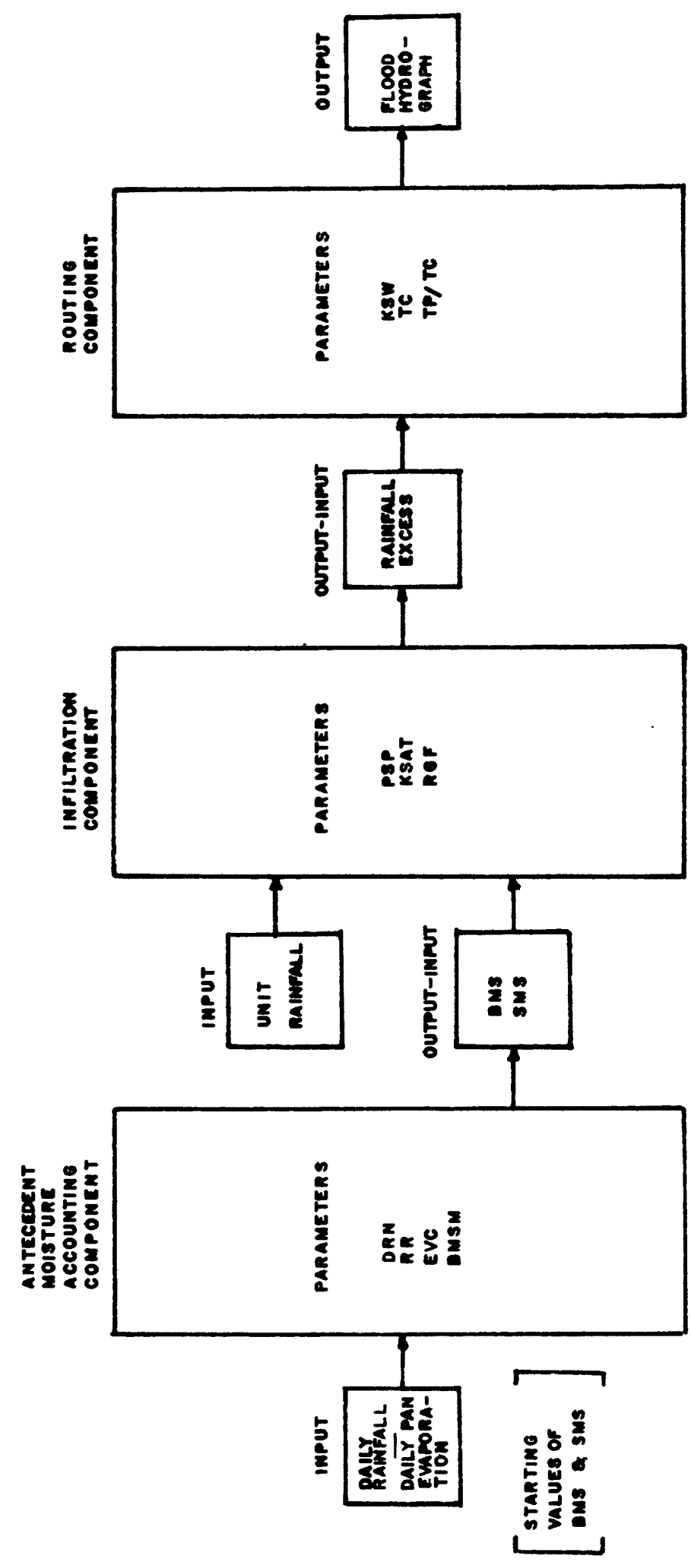

웅 


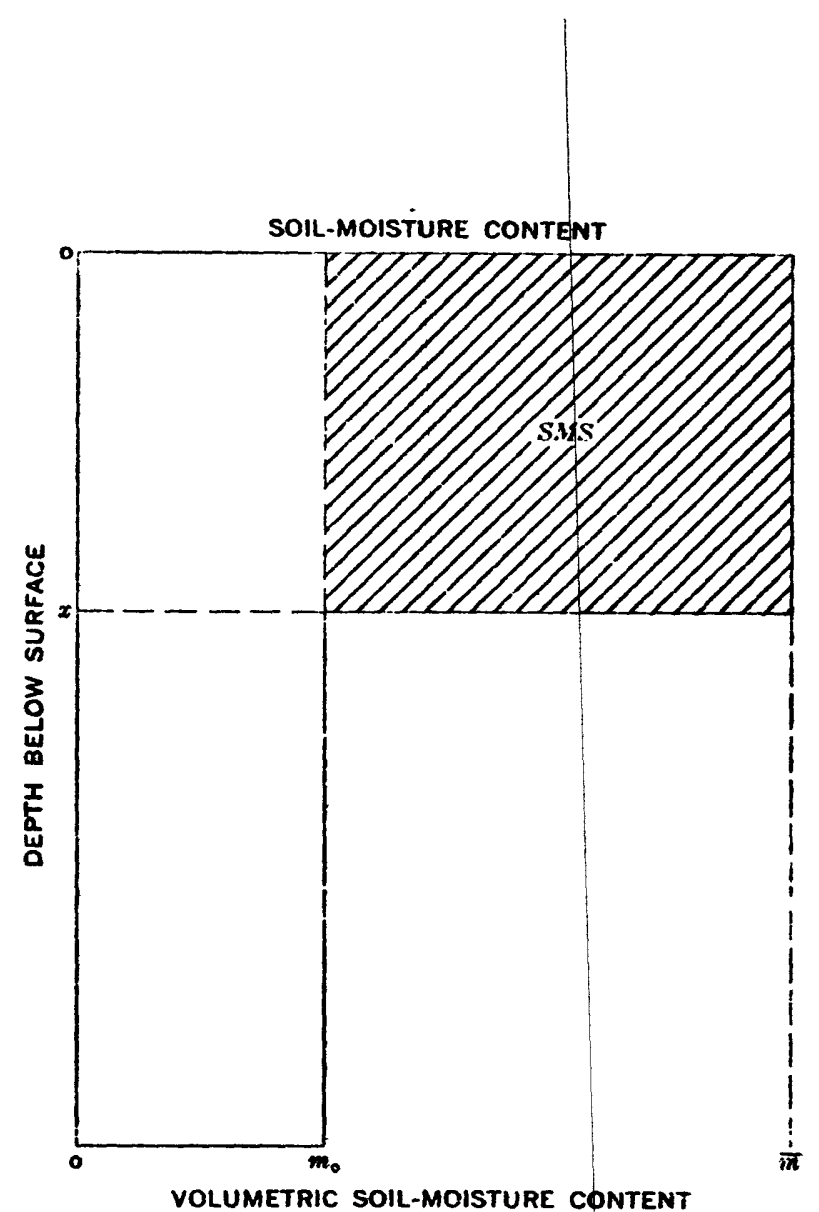

FIGURE 4.--Schematic diagram of the two-layered soilmoisture profile used with the infiltration equation in the model. The initial uniform soil-moisture content, stated as a proportion of total volume, is $m_{O}$, field capacity content is $m$, and the depth of the wetted layer is $x$. The amount of infiltrated moisture $(S M S)$ is $\left(m-m_{0}\right) \cdot x$, and is shown as the hachured area. That portion of antecedent moisture contained in the wetted layer is $m_{0} \cdot x$, and is shown as the unhachured area above the depth $x$ in the profile. (Dawdy, Lichty, and Bergmann, 1972, p.6) 
SMS portrays accumulated infiltration and during storm periods all the infiltration is added to SMS. BMS is used to compute the relative soil moisture deficit. Evapotranspiration demand is met from SMS as long as storage is greater than zero. (It is assumed that evapotranspiration losses occur at potential rate.) If storage in SMS is zero then evapotranspiration demand is met by BMS. Input to the antecedent moisture component is daily rainfall and daily pan evaporation. Output from the antecedent moisture component is the amount of BMS and infiltrated SMS.

The infiltration component is responsible for the division of rainfall into infiltration and surface runoff (rainfall excess). Input to the infiltration component are unit-time storm rainfall, BMS, and SMS. Parameters used in this component are PSP, KSAT, and RGF (table 1). Output is rainfall excess.

The surface routing component is responsible for routing the rainfall excess to the basin outlet. The routing component uses three parameters, KSW, TC, and TP/TC (table 1 and fig. 3). The Clark flood-routing method (Dawdy, Litchy, and Bergmann, 1972, p. 8) is used to translate the rainfall excess to a time-area curve and route it through a single linear storage reservoir to the basin outlet. Output for the surface routing component is the flood hydrograph. 
Model Calibration

The ten parameter values which control the operation of the model must be evaluated for each site. The model uses a hill-climbing technique of parameter optimization. The optimization scheme compares the simulated record with the observed record, then changes one parameter value, repeats the computations, and compares the newly simulated record with the observed record. The process of individually changing parameter values and computing a new simulated record is repeated until a satisfactory comparison of simulated and observed record is obtained.

The model calibration process is divided into three phases; volume adjustment phase, routing phase, and combined phase. During the volume adjustment phase, the first seven parameters (table 1) controlling the moisture accounting and infiltration components of the model are adjusted to minimize the error in computing volumes of runoff. In the routing phase the other three parameters, controlling the surface routing component are adjusted to determine optimum values for reproducing flood peaks, given the correct volume of runoff. In the combined phase the three routing parameters are held constant and the initial seven parameters are adjusted to obtain the best reproduction of the obseryed peaks.

Calibration for a specific site requires concurrent data on streamflow, rainfall, and evaporation. Some assumptions made in the calibration process are:

1. That the rainfall recorded at a single rain gage is representative of that occurring throughout the basin. 
2. That the input data are accurate.

3. That basin changes have not destroyed the homogeneity of flood records during the period used in the model calibration.

4. That the long-term rainfall and evaporation records available from other sites are applicable to the drainage basin.

After the first calibration run, a screening process is used to identify and eliminate those storms which show appreciable differences between the computed and observed runoff volume or peak discharge. Nonuniformity of rainfall over the basin and recorder malfunctions account for most of the differences between observed and simulated volumes and peaks. New calibration runs are made, using the screened data, to find the optimum set of parameter values.

\section{HYDROLOGIC ANALYSIS}

\section{Model Studies}

Preliminary model calibrations have been run on eight rainfall/ runoff gaging stations, 20 more are ready for calibration, and two stations lack adequate definition of the stage-discharge relationship.

Table 2 is a summary of the model parameters for the eight stations that have been calibrated. The standard error of estimate for these stations ranged from 25 to 50 percent. Additional storm data are now available and new model calibrations will be run in an attempt to reduce the standard error of estimate. 


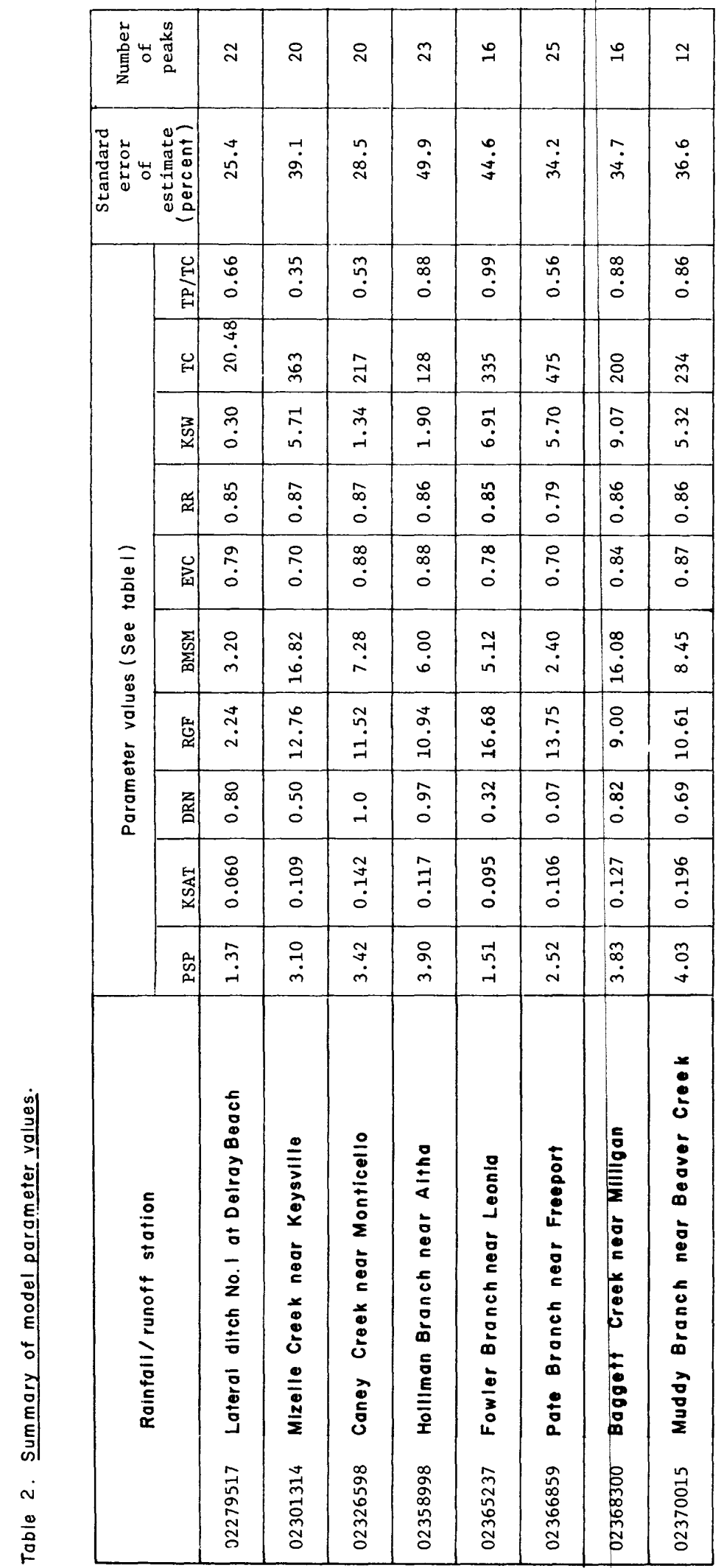


Use of the U.S. Geological Survey rainfall/runoff model will be limited to the rainfall/runoff gaging stations. Flood frequency curves for crest-stage and regular gaging stations, with 10 or more years of record, will be developed by use of the log Pearson Type III analysis (U.S. Water Resources Council, 1976).

\section{Caney Creek Model}

Caney Creek is the only rainfall/runoff gaging station for which all of the following have been completed: 1) model calibrated; and 2) simulation of peaks from long-term rainfall record; flood frequency curve developed using simulated peaks.

Three optimization runs were made to calibrate the model for Caney Creek. After the first run the output was scanned and 20 of the original 23 storm events were used in the second and third runs. Peaks excluded from the calibration are March 30, 1972, October 27, 1972, and August 6,1973 . These storm events were excluded because of nonrepresentative rainfall. On March 30, 1972 and August 6, 1973 the rainfall was concentrated more in the upper part of the basin whereas on October 27, 1972 the rainfall was more concentrated at the recording gage.

The final values used for the 10 parameters are shown in table 3. A plot of the observed peak (ordinate) and the simulated peak (abscissa) is shown in figure 5. The standard error of estimate for the third optimization run was 28 percent.

For the calibrated model for Caney Creek, a long-term record of rainfall and evaporation was used as input to generate a long-term record of simulated flood peaks. Daily rainfall for 1902-63, and 5-minute 


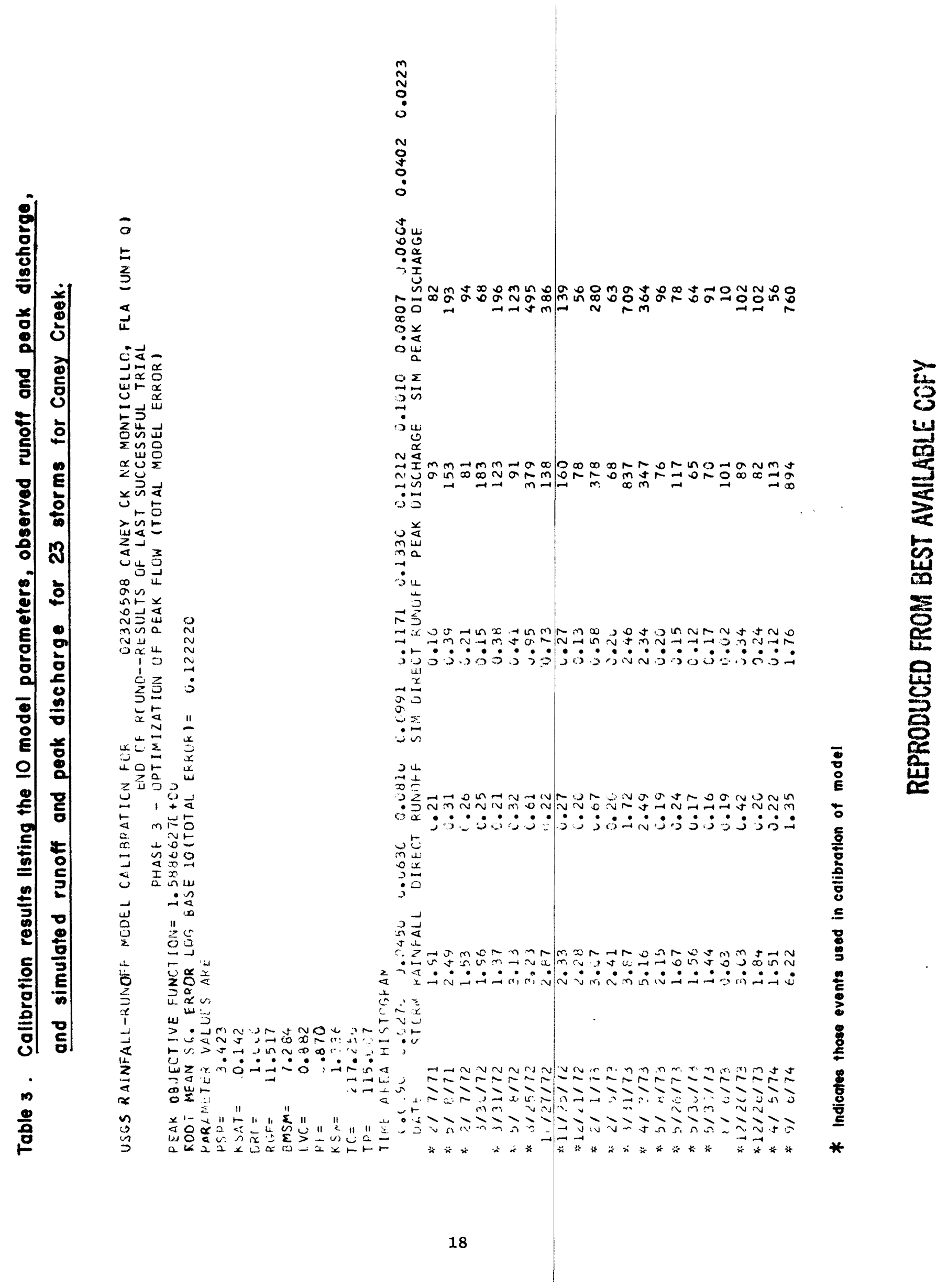


USGS RAIIJFALL-RUNOFF MODEL CALIBRATIOIN FOR 02326590 CAINEY CK INR MOÑTICELLO, FLA (UIIT Q)

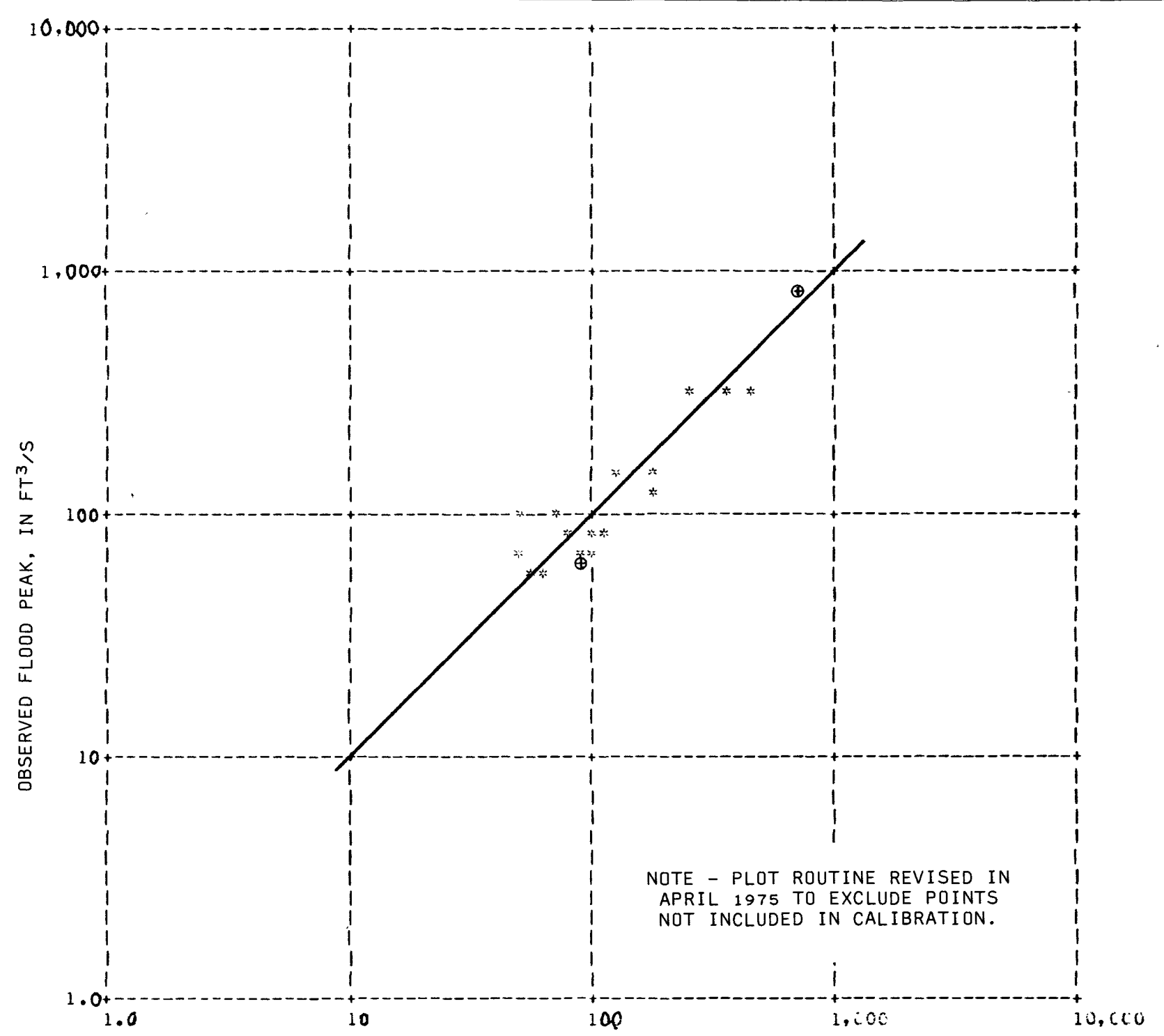

IJUIEBER OF POIITSS PLOTTED $=20$ SIMULATED FLOOD PEAK, IN FT ${ }^{3} / \mathrm{S}$

IUUBER OF IULTIPLE PTS. $=2$

IJUIBBER OF P'TS. OFF GRID $=0$

ITUIBER OF POIITS ONITTED $=3$

$\oplus$ NULTIFLF PCINTS

FIGURE 5.--Graph of observed flood peak versus simulated flood peak. 
unit rainfall for 267 selected storms for Pensacola, Florida, about 200 miles west of Caney Creek, were used as input data for the Caney Creek model. Daily pan evaporation record, 1963 to 1973, was available from the Milton Florida Experiment Station about 175 miles west. A computer program was used to fit a harmonic (sine-cosine) function which then generated a daily evaporation record from 1902 to 1962.

Simulated flood peaks for 1902-68 were generated and used as input to develop a flood frequency curve (see fig. 6) based on a log Pearson Type III distribution (U.S. Water Resources Council, 1976). 


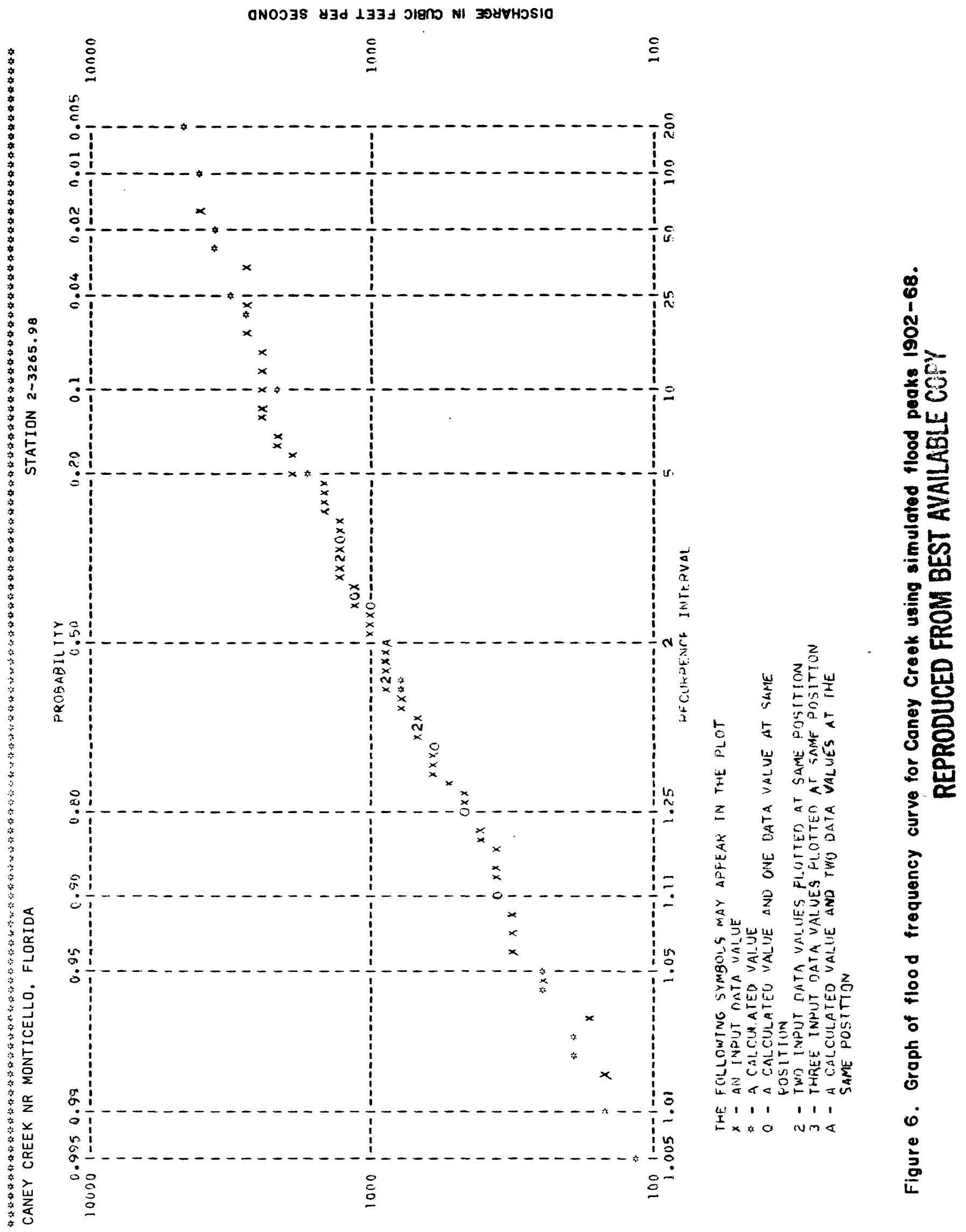


Barnes, H. H., and Golden, H. G., 1966, Magnitude and frequency of

floods in the United States, Part 2-B: U.S. Geol. Survey WaterSupply Paper 1674, 409 p., p1. 1.

Benson, M. A., 1962, Factors influencing the occurrence of floods in a humid region of diverse terrain: U.S. Geol. Survey WaterSupply Paper 1580-B, 64 p. , 1964, Factors affecting the occurrence of floods in the Southwest: U.S. Geol. Survey Water-Supply Paper 1580-D, 70 p. Dawdy, D. R., Lichty, R. W., and Bergman, J. M., 1972, A rainfall-runoff simulation model for estimation of flood peaks from small drainage basins: U.S. Geol. Survey Prof. Paper 506-B, 28 p. Pride, R. W., 1958, Floods in Florida, magnitude and frequency: U.S. Geol. Survey open-file report, 136 p.

U.S.Water Resources Council, 1976, A uniform technique for determining flood-flow frequencies: U.S. Water Resources Council Bul1. 17, 26 p. 